Download

https://doi.org/10.17721/2308-135 $\underline{\text { X }} . \underline{.2019 .45 .112-119}$

UDC 331.5(438):331.556.4(477)]:303.71

Arkadiusz Przybyłka, PhD in Economics, University of Economics in Katowice, ul. 1-go Maja 50, Katowice, Poland, e-mail: arekp@ue.katowice.pl

\title{
EMPLOYEES FROM UKRAINE ON THE POLISH LABOUR MARKET
}

Purpose of the research: show how many people from Ukraine work legally in Poland.

Methodology: Research is based on the analysis of official statistical data. Stats of work permits and arrivals were used. Also analyzed legal acts regulating this issue.

Results. According to the European Commission, the situation on the Polish labour market is "the best in the recent history of the country". Unemployment has dropped to such a level that labour shortages can limit economic activity in the country. Lower employee resources are caused by unfavourable demographic changes and lowering the retirement age. Therefore, the 
number of employees from other countries has been growing for several years. Shortages in the labour market are mitigated by immigration coming to Poland. Of the foreigners, the largest number of employees is form Ukraine. According to the data from the Ministry of Labour and Social Policy in 2017, the largest number of work permits were issued to Ukrainian citizens 192,5 thousand, which accounted for $82 \%$ of the total and, at the same time, $81 \%$ higher than in 2016.

૫ Scientific novelty: So far, no comprehensive analysis describing debated issue.

The practical significance: The research is to help illustrate trends in this issue. In addition, indicate how people from Ukraine can be employed.

Keywords: labour market, employees, employment, Ukrainians.

References:

1.Butkiewicz-Schodowska A., Kapitał ludzki we współczesnym zarządzaniu przedsiębiorstwami. Uniwersytet Szczeciński. Szczecin 2015.

2.Kryńska E., Kwiatkowski E., Podstawy wiedzy o rynku pracy. UŁ, Łódź 2013.

3.Kuczewska I., Sytuacja na rynku pracy a zmiany w konsumpcji polskich gospodarstw domowych. Konsumpcja i Rozwój 2013, nr 2(5).

4. Makowski M., Zatrudnienie cudzoziemców po zmianach w 2018 r.. INFOR. Warszawa 2018. sprawie wydawania zezwolenia na pracę cudzoziemca oraz wpisu oświadczenia o powierzeniu 
wykonywania pracy cudzoziemcowi do ewidencji oświadczeń (Dz. U. 2017, poz. 2345).

6. Rozporządzenie Ministra Rodziny Pracy i Polityki Społecznej z dnia 8 grudnia 2017 r. w sprawie podklas działalności według Polskiej Klasyfikacji Działalności (PKD), w których wydawane są zezwolenia na pracę sezonową cudzoziemca (Dz. U. 2017, poz. 2348).

7. Rozporządzenie Parlamentu Europejskiego I Rady (UE) 2017/850 z dnia 17 maja 2017 r. Zmieniające rozporządzenie wymieniające państwa trzecie, których obywatele muszą posiadać wizy podczas przekraczania granic zewnętrznych, oraz te, których obywatele są zwolnieni z tego wymogu (Ukraina) (Dz. U. UE L 133 z dnia 22 maja 2017 r.).

8.Rynek pracy w Polsce. Raport ECR Polska. Poznań 2017.

9.Business Insider. Polska. [electronic resource]. - Access: https://businessinsider.com.pl/finan $\underline{\mathrm{se} /}$

ukraincy-pracujacy-w-polsce-barometr-imigracji-zarobkowej-2018/t9ftrbb 